\title{
Study of the action of tamoxifen on the mammary gland epithelium of premenopausal patients by lysosome quantification
}

\author{
Department of Gynecology and Obstetrics, Federal University of São Paulo, Escola Paulista de Medicina -
}

São Paulo, SP, Brazil

Tamoxifen is an antiestrogen drug widely utilized for the adjuvant hormonal treatment of breast carcinoma. Its use in the primary prophylaxis of this disease is currently being proposed. Although the drug has few side effects, its precise action on breast tissue that has not undergone neoplastic transformation has not been fully elucidated. This prospective, randomized study assessed the estrogen activity of tamoxifen on the mammary gland epithelium of premenopausal patients using a quantitative analysis of mammary epithelium lysosomes identified by the cytochemical technique of GOMORI for acid phosphatase and by light microscopy. Tamoxifen significantly increased the number of lysosomes only during the secretory phase of the menstrual cycle. We concluded that the early effect of the drug on normal mammary tissue is synergistic with the effect of estrogen during the premenopausal period.

\section{INTRODUCTION}

$\mathrm{T}$ amoxifen is considered to be an antiestrogen nonsteroid drug that inhibits the growth of breast carcinoma, thus representing the drug of choice for hormonal treatment of this disease.' Recent studies have shown a lower incidence of primary cancer and cyclic pain in the contralateral breast of patients with carcinoma treated with tamoxifen..$^{1-3}$ Thus, it is of great interest to know how the drug acts upon normal breasts, to the end of it being used as a primary prophylaxis of breast carcinoma in women at high-risk for developing this disease. ${ }^{3-5}$

Lysosomes are cytoplasmic organelles containing lytic enzymes and covered with semipermeable

\section{Address for correspondence:}

membranes, and were first studied by DE DUVE et al. ${ }^{6}$ These investigators identified these organelles by cell fractionation techniques followed by centrifugation, which led to the observation of vesicles rich in hydrolytic enzymes.

Studies relating the mammary gland to lysosomes have shown a larger number of these organelles in breast tumor cells compared to the normal adjacent parenchyma. ${ }^{7.8}$ Lysosomes are important markers of estrogen-mediated cell proliferation in the breast parenchyma. ${ }^{7.8}$

GIRÃO et al.," studying the numerical variation of lysosomes in the mammary epithelium during the menstrual cycle, observed a significantly greater amount of lysosomes during the first phase than in the second phase, demonstrating that the number of lysosomes reflects estrogen activity.

The objective of this study was to assess the estrogen activity of tamoxifen on the epithelium of the mammary gland of premenopausal women by lysosome quantification. 


\section{OBJECTIVE}

To evaluate quantitatively the lysosomes of the human mammary gland epithelium in the proliferative and secretory phase of the menstrual cycle during tamoxifen administration, and to compare the values obtained with those detected in untreated women during these same phases.

\section{MATERIALS AND METHODS}

The study was carried out on 33 women aged 15-37 with fibroadenomas $1-3 \mathrm{~cm}$ in diameter which were removed and submitted to biopsy. Normal parenchyma samples were obtained from breast tissue situated at least $2 \mathrm{~cm}$ from the fibroadenoma at the time of surgical exeresis under local anesthesia. All patients gave informed written consent and the study was approved by the Ethics Committee of Hospital São Paulo.

The patients were divided randomly into two groups: Group A (control) consisted of 16 patients, and Group B consisted of 17 patients who took tamoxifen ( $20 \mathrm{mg} /$ day) for 30 days before surgery.

All patients had normal menstrual cycles. The cycle phase was characterized on the basis of the date of last menstruation and measurement of plasma progesterone. Patients with endocrine disease, pregnant patients or those who had taken hormones during the prior 12 months were excluded from the study, as were also patients whose biopsy did not confirm the presence of a fibroadenoma in the nodule or normality of the adjacent parenchyma.

The choice of menstrual cycle phase for exeresis of the nodule was aleatory for both groups, but the dates were fixed for a period between the 7 th and 10 th day during the first phase, and between the 21st and 23rd day during the second.

Lysosomes were identified by the cytochemical method of acid phosphatase detection, ${ }^{10}$ and counts were carried out using the PRICOLI" andMARTINS ${ }^{12}$ methods. Counts were carried out in a double-blind manner on 25 reticulated areas per $400 \mathrm{x}$ field completely filled with epithelial cells. Data were analyzed statistically by the Mann-Whitney and Fisher exact tests. ${ }^{13}$

\section{RESULTS}

Tamoxifen significantly increased the number of lysosomes in the mammary epithelium during the second phase of the menstrual cycle (Figs. 1 and 2).

During tamoxifen administration, the number of lysosomes remained stable in both phases of the menstrual cycle (Table 1).

Progesterone levels were significantly higher in group B patients during the luteal phase of the menstrual cycle (Table 2).

\section{DISCUSSION}

Tamoxifen is the most widely-used drug for chemoprophylaxis of breast carcinoma. However, its action on the normal mammary lobule before and after menopause is still unknown. ${ }^{14-16}$

It is difficult to create an experimental model that will reproduce the complex endocrine interaction of the human breast, and there are obvious ethical restrictions with respect to taking biopsies from the normal breast.

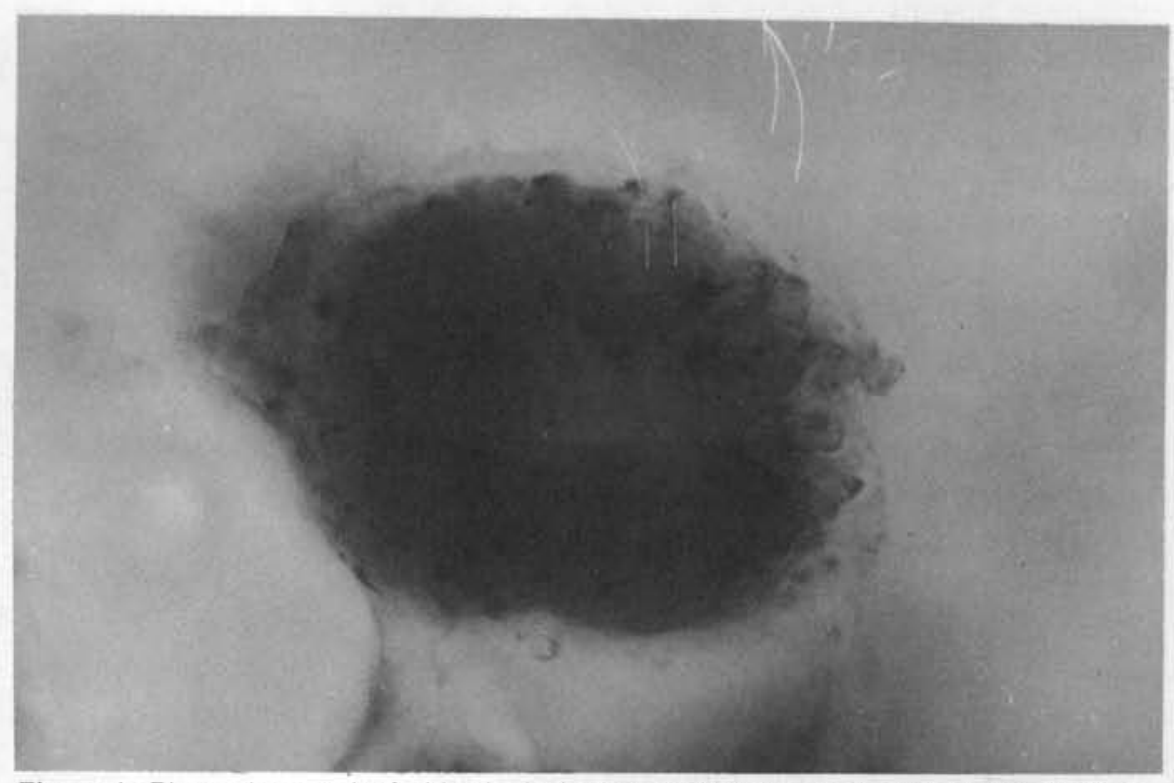

Figure 1 - Photomicrograph of a histological section of human mammary gland epithelium during the secretory phase from a patient NOT treated with tamoxifen (Gomori method for acid phosphatase. Magnification. $\pm 1.440 \mathrm{X}$ ). 
Table 1

Number of lysosomes in the breast epithelium of patients from Group A (control) and Group B (tamoxifen) during the proliferative and secretory phases of the cell cycle.

\begin{tabular}{ccccc}
\hline & \multicolumn{2}{c}{ Group A } & \multicolumn{2}{c}{ Group B } \\
& Proliferative & Secretory & Proliferative & Secretory \\
\hline 147 & 94 & 86 & 75 \\
131 & 131 & 104 & 126 \\
138 & 81 & 131 & 113 \\
& 119 & 87 & 121 & 136 \\
& 128 & 85 & 137 & 113 \\
& 140 & 115 & 117 & 139 \\
& 169 & 106 & 150 & 175 \\
& 101 & & 141 & 134 \\
& 131 & & & 188 \\
\hline Mean & 133 & 99 & 123 & 133 \\
\hline
\end{tabular}

Mann-Whitney Test

1st)

$\begin{array}{ll}\text { Proliferative } & \text { secretory } \\ \text { Group A } & \text { Group B } \\ \text { Ucalc }=6^{\star} & \text { Ucalc }=32 \\ \text { Ucrit }=12 & \text { Ucrit }=15\end{array}$

2nd)

Group A x B

Proliferative

Ucalc $=28$

Ucrit $=15$

Ucalc $=12^{*}$ tissues. The method used for breast tissue is reproducible as demonstrated by ZAMITH et al. ${ }^{20}$ and GIRÃO et al. ${ }^{9}$ These investigators observed a larger number of lysosomes during the first phase of the cycle in breast tissue from premenopausal women, in agreement with the serum level of estradiol.

Tamoxifen administered before menopause first causes an increase in serum estrogen and progesterone levels, possibly initialing the proliferation of the mammary epithelium. ${ }^{21}$ The increased number of lysosomes observed during the second phase of the cycle in women taking tamoxifen confirms the estrogen agonist effect of the drug on premenopausal women.

On the other hand, the increased concentration of active serum progesterone activates the enzyme 17beta-hydroxysteroid oxidoreductase, which favors the conversion of estrone to estradiol in breast tissue, which in turns increases estrogen activity. ${ }^{22}$

Recent studies using molecular

The tissue fragment utilized in the present study was obtained from patients with fibroadenoma who did not respond to tamoxifen treatment, after authorization by the Medical Ethics Committee of Hospital São Paulo.

There are numerous theories attempting to explain the antiproliferative action of this drug on neoplastic tissue. The major mechanism of action, however, is thought to be the combination of tamoxifen with nuclear estrogen receptor protein (ERP), which produces a G1 block and decreases production of growthstimulating proteins such as transforming growth factor alpha (TGF-a), and stimulation of growthinhibiting proteins like transforming growth factor beta (TGF- $\beta$ ). ${ }^{17-19}$

Tamoxifen is predominantly a tumoristatic agent; it doubles the levels of sex hormone-binding globulin (SHBG) and may therefore exert its antiestrogen effect by making it unavailable to breast cells.'

The quantitative variation in intracellular lysosomes indirectly measures estrogen activity on target

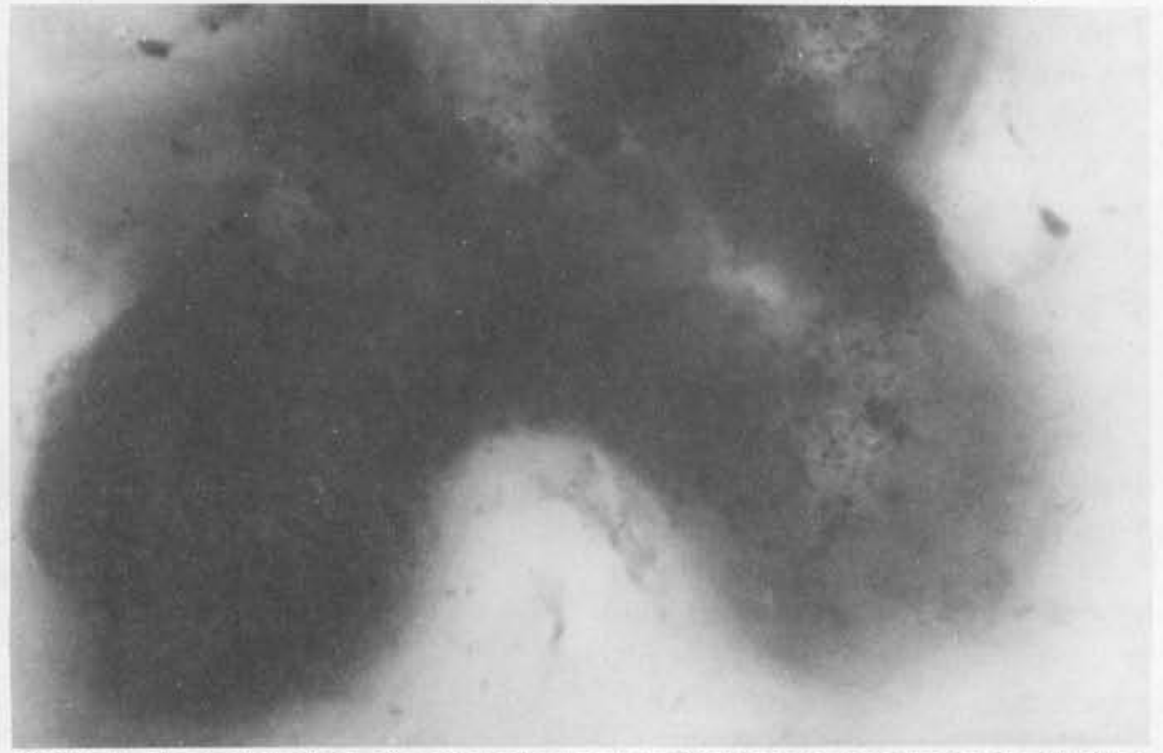

Figure 2 - Photomicrograph of a histological section of human mammary gland epithelium during the secretory phase from a patient treated with tamoxifen (Gomori method for acid phosphatase. Magnification. $\pm 1.4440 \mathrm{X}$ ). 
Table2

Serum progesterone levels $(\mathrm{ng} / \mathrm{ml})$ in patients from Group A (control) and Group B (tamoxifen) during the proliferative and secretory phases of the menstrual cycle.

\begin{tabular}{ccccc}
\hline & Group A & GroupB & GroupA & Group B \\
\hline & 0.4 & 0.5 & 6.1 & 8.9 \\
0.9 & 0.8 & 7.9 & 13.7 \\
& 0.4 & 0.5 & 6.5 & 24.6 \\
& 0.7 & 0.6 & 6.5 & 6.8 \\
& 0.6 & 0.8 & 12.7 & 18.9 \\
& 0.4 & 0.3 & 4.0 & 36.9 \\
& 0.5 & 0.1 & 16.3 & 34.2 \\
& 0.7 & 0.1 & & 47.0 \\
& 0.3 & & & 33.0 \\
Meen & 0.54 & 0.46 & 8.5 & 24.89 \\
\hline
\end{tabular}

Mann-Whitney Test

1st)

Proliferative
Group AxB
Ucalc $=31$
Ucrit $=15$

2) Secretory

Group AxB

Ucalc $=6^{*}$

Ucrit $=12$ of estrogen receptors, reduction of TGF-a and increase of TGF-B.

Future studies on patients using tamoxifen for long periods of time are needed to better evaluate the endocrine effect of the drug on normal breast tissue, thus permitting a more rational indication of the drug for treatment of benign diseases and for cancer chemoprophylaxis.

\section{CONCLUSION}

We conclude that tamoxifen significantly increased the number of lysosomes in the mammary epithelium in the second phase of the menstrual cycle, with levels similar to those detected in the proliferative phase for both groups. Thus, the drug appears to have a synergistic effect with estrogen during the premenopausal period.

\section{Resumo}

Introdução: O tamoxifeno é uma droga antiestrogênica largamente utilizada no tratamento hormonal adjuvante do carcinoma mamário. Atualmente, vem sendo proposto a sua utilizaçāo na profilaxia primária desta doença. Trata-se de uma droga de poucos efeitos colaterais que ainda nāo tem estabelecido a exata forma de ação em tecido mamário que nāo sofreu transformaçāo neoplásica. Objetivo: Avaliar a atividade estrogênica do tamoxifeno no epitélio da glândula mamária de pacientes na pré-menopausa. Tipo de estudo: Prospectivo - randômico.Metodologia: Análise quantitativa dos lisossomos do epitélio mamário identificados pela técnica citoquímica de GOMORI para a fosfatase ácida e microscopia de luz. Resultados: Observouse que o tamoxifeno aumentou de forma significante, o número de lisossomos somente na fase secretora do ciclo menstrual. Conclusão: Concluiu-se que o efeito inicial da droga em tecido mamário normal, na pré-menopausa, tem efeito sinérgico ao estrogênio. 


\section{REFERENCES}

1. Jordan VC. Target hormone therapy for breast cancer. Hospital Practice 1993;15:55-62.

2. Cuzick J, Baum M. Tamoxifen and contralateral breast cancer. Lancet 1985;ii: 282.

3. Fornander T, Rutqvist LE, Cedermark et al. Adjuvant tamoxifen in early breast cancer: Occurrence of new primary cancers. Lancet 1989;i:117-20.

4. Nolvadex Adjuvant Trial Organisation. Controlled trial of tamoxifen as a single adjuvant agent in the management of early breast cancer. Br J Cancer 1988;57:608-11.

5. Powles TJ, Davey J, McKinna A. Chemoprevention of breast cancer. Acta Oncol 1990;28:865-7.

6. De Duve C, Berthet J, Hers HG, Dupret L. Le système hexosephosphatase specifique dans le foie. Bull Soc Chim Biol 1949;31:1242-53.

7. Podhajcer OL, Filmus JE, Mordoh J. Characterization of lysosomal acid phosphatase from normal and malignant mammary tissue. Clin Chem 1986;32:279-82.

8. Talukdar C, Ghosh S. Peroxidase activities in human breast tumours in relation to menstrual status of the patients. Indian J Res 1984:79:801-5

9. Girão MJBC, Baracat EC, Lima GR, Simões MJ. Variacions cuantitativas de los lisosomas en el epitelio alveolar de la glandula mamaria humana en las fases proliferativa y secretora do ciclo menstrual. Rev Chil Obstet Ginecol 1991;56(2):107-10.

10. Gomori G. Microscopic histochemistry: Principles and practice. Chicago: University Chicago Press, 1952:137-221.

11. Pricoli TI. Estudo comparativo dos lisossomos do hepatócito nas formas hepato-intestinal e hepato-esplênica da esquistossomose mansônica humana. Tese de Doutoramento, Escola Paulista de Medicina. São Paulo 1972:78.

12. Martins NV. Variações quantitativas dos lisossomos no epitélio endometrial de ratas na fase de estro, ooforectomizadas e ooforectomizadas tratadas com estrogênio. São Paulo, 1983:50. [Tese Doutorado - Escola Paulista de Medicina].
13. Siegel S. Estadistica no paramétrica aplicada a las ciencias de la conducta. $2^{a}$ reimp. Mexico: Trillas, 1975:143-55.

14. Costa A, Love RR. Breast cancer prevention with tamoxifen: The Madison meetings. Eur J Cancer 1990;26:656-7.

15. Fentiman IS. The role of tamoxifen in the prevention of breast cancer. Eur J Cancer 1990;26:655-6.

16. Fentiman IS, Owles TJ. Tamoxifen and benign breast problems. Lancet 1987;ii:1070-1.

17. Bond JP, Sasson S, Notides AC. The binding of estrogen and estrogen antagonists to the estrogen receptor. Arch Biochem Biophys 1992;296:583-91.

18. Leis HP. The role of tamoxifen in prevention and treatment of benign and malignant breast lesions: A chemopreventive. Int Surg 1993;78:176-82.

19. Noguchi S, Motomura K, Inaji H, Imaoka S, Koyama H. Up-regulation of estrogen receptor by tamoxifen in human breast cancer. Cancer 1993;71:1266-72.

20. Zamith R, Baracat EC, Rodrigues De Lima G, Gebrim LH, Simões MJ. Quantitative study of the lysosomes of epithelial cells from human mammary glands and fibroadenoma during proliferative and secretory phase of the menstrual cycle. Bull Assoc Anat 1994;78:19-21.

21. Sutherland MC, Osborne CK. Tamoxifen in the premenopausal patients with metastatic breast cancer: A rev́iew. J Clin Oncol 1991;9:1283-97.

22. Nazário ACP, Rodrigues De Lima G, Simões MJ, Novo NF. Cell kinetics of the human mammary lobule during the proliferative and secretory phase of the menstrual cycle. Bull Assoc Anat 1995;79(244):23-7.

23. Pham TA, Elliston JF, Nawaz Z, Mxdonnell DP, Tsa MJ, O'Malley BW. Antiestrogen can establish nonproductive receptor complexes and alter chromatin structure at target enhancers. Proc Natl Acad Sci 1991;88:3125-9.

24. Tzukerman MT, Esty A, Santiso-Mere D, et al. Human estrogen receptor transactivational capacity is determined by both cellular and promoter context and mediated by two functionally distinct intramolecular regions. Mol Endocrinol 1994;8:21-30. 